\title{
Water-Hyacinth from Nile River: Chemical Contents, Nutrient Elements and Heavy Metals
}

\author{
H. I. Abdel Shafy", M. R. Farid", and A. M. Shams El-Din ${ }^{* *}$ \\ Water Research and Pollution Control Department, National \\ Research Center, Dokki, Cairo, "Department of Horticulture, \\ Faculty of Agriculture, Minufiya University and ${ }^{* *}$ Department \\ of Plant Protection, Faculty of Agriculture, Moshtohor, Egypt.
}

\begin{abstract}
CAMPLES of water-hyacinth were collected from the main stream of Nile River near the location of El-Kanater El-Khayria. Plant samples were taken at three intervals during March, August and December during the years 2014 and 2015 to study the seasonal variation. The harvested plants were divided into leaves, stems and roots and were subjected for general analysis of crude protein, ash, crude fat, fibers and nitrogen free extract.

Meanwhile, sugars and carbohydrates were determined in the different plant samples. Plant stems showed maximum reducing sugars content. On the other hand, leaves demonstrated the highest level of both non-reducing and total sugars. The mineral analysis revealed that sodium, potassium, magnesium and calcium were found in relatively higher level. Iron, zinc and manganese were within moderate concentration. Copper, lead and cobalt detected in plant tissues were in minor amounts. Results indicated that the level of the determined chemical contents depended mainly on the sampling date and the plant organ.
\end{abstract}

Water-hyacinth (Eichhornia crassipes) is an important aquatic plant that is widely spreading in many countries in the world. The chemical composition of water-hyacinth varies considerably according to the location and season ${ }^{(1,2)}$.

El-Kadi ${ }^{(1)}$ mentioned that constituents of dried water-hyacinth on dry weight basis were $10 \%$ crude protein, $11 \%$ ash and $79 \%$ organic matter. Fayed and Abdel-Shafy ${ }^{(2)}$ confirmed that the dry matter content of different plant organs of water hyacinth is within $6.87,4.22$ and $7.88 \%$ for leaves, stems and roots, respectively.

Fayed and Abdel-Shafy ${ }^{(3)}$ found that the hay prepared from water-hyacinth contains 10.76 crude protein, $4.94 \%$ fat, $17.9 \%$ crude fibers, $44.3 \%$ nitrogen free extract, $22.1 \%$ ash, $1.42 \%$ calcium and $0.58 \%$ phosphorus.

\#Corresponding author: hshafywater@yahoo.com 
Abou-Bakr et al. ${ }^{(4)}$ reported that water-hyacinth contains $49.6 \%$ protein, $16 \%$ total lipids, $26.9 \%$ total carbohydrates, $11.7 \%$ fibers and $5.8 \%$ ash.

Meanwhile, different investigators ${ }^{(2,5)}$ showed that water-hyacinth has the ability to uptake toxic heavy metals such as cadmium, zinc, copper and lead within their tissues. They, therefore, concluded that such plants could be used as a biological indicator for environmental contamination by heavy metals. The same conclusion was stated by other investigators ${ }^{(3,6,7)}$. The following ranges: 63-277, 220-280, 55-60, 5-10 and $0-<5 \mathrm{mg} / \mathrm{l}$ for $\mathrm{Fe}, \mathrm{Mn}, \mathrm{Zn}, \mathrm{Cu}$ and $\mathrm{Pb}$ respectively were reported by several investigators ${ }^{(8,9)}$.

There has been an emphasis on converting aquatic weeds into useful resources, including animal feed, composted fertilizer or for bio-energy production via anaerobic conversion ${ }^{(10-13)}$. In this respect, it was stated that the presence of heavy metals in the plant could have negative impact on the energy production ${ }^{(14,15)}$.

Several experiments were conducted to study the possibility of using of water-hyacinth as animal feed stuff ${ }^{(16)}$. Meanwhile, several attempts were carried out for utilization of water-hyacinth as a compost fertilizer ${ }^{(1,17,18)}$.

The most economic value, however, of these aquatic plants is their potential effect for the removal of heavy metals from wastewater. Several reports showed that water-hyacinth has moderate capacity to accumulate heavy metals from contaminated aquatic system ${ }^{(2)}$. That is why the aquatic plants are commonly employed in the artificial wetlands system for the treatment of wastewater ${ }^{(19-25)}$.

The aim of the present study is to investigate the chemical composition, macro-elements including, sodium, potassium, calcium as well as the level of heavy metals in the water-hyacinth (Eichhornia crassipes) plant. This study is concerned with the water-hyacinth plants that are collected from the aquatic environment of the Nile River around Cairo, Egypt.

\section{Materials and Methods}

Samples of water-hyacinth were collected from the main stream of Nile River near the location of El-Kanater El-Khayria. Plants were harvested during March, October and December, for two successive years namely, 2014 and 2015 to represent the different stages of growth as well as the seasonal variation.

Samples were washed and brought to the laboratory in polyethylene bags. Each plant sample was partitioned into leaves, stems and roots. All the partitioned plant parts were immersed in $95 \%$ ethyl alcohol to stop enzymatic activities.

Egypt. J. Chem. 59, No. 2 (2016) 
These samples were used for the determination of chlorophyll, sugars, and carbohydrates and free amino acids content analysis. Other fresh samples of leaves, stems and roots were oven dried at $70^{\circ} \mathrm{C}$ for $24 \mathrm{hr}$, the dried plant materials were kept for the other chemical analysis.

Determination of ash

Other samples were ash dried using a muffle heater at $800^{\circ} \mathrm{C}$ for $24 \mathrm{hr}$ as described by A.O.A.C., $1985^{(26)}$ for the determination of the ash contents.

Determination of nitrogen, protein, crude fat and crude fibers

Total organic nitrogen and crude protein were determined by the usual Kjeldahl method ${ }^{(26)}$.

For the determination of crude fat: Total lipids were extracted in a soxhlet apparatus at $\left(60-80^{\circ} \mathrm{C}\right)$ for $8 \mathrm{hrs}$ using petroleum ether according to A.O.A.C., $1985^{(26)}$.

Crude fibers were estimated by the subsequent boiling in sulphuric acid (200 $\mathrm{ml}, 1.25 \% \mathrm{~W} / \mathrm{V})$ and sodium hydroxide $(200 \mathrm{ml}, 1.25 \%)$ as described by A.O.A.C., $1985^{(26)}$.

Determination of the nitrogen free extract

Nitrogen free extract was calculated by differences.

Determination of total carbohydrates and sugars content

Total carbohydrates were hydrolyzed using $1 \mathrm{~N}$ sulphuric acid in sealed tubes at $100^{\circ} \mathrm{C}$ for $24 \mathrm{hr}$. Total soluble sugars were extracted by $80 \%$ ethanol for $6 \mathrm{hr}$. Total carbohydrates and sugars were determined using the method described by Dubois et al. ${ }^{(27)}$. Reducing sugars were determined in the ethanol extract according to A.O.A.C. method ${ }^{(26)}$.

\section{Determination of metals content}

The dried samples were digested in Kjeldah flasks using a mixture of nitricperchloric-sulphuric acid mixture (3:2:1 by volume as V/V/V). After complete digestion, the solution was cooled and transferred into a volumetric flash and made up to the volume with double distilled water. $\mathrm{Na}, \mathrm{K}, \mathrm{Ca}, \mathrm{Mg}, \mathrm{Fe}$, $\mathrm{Mn}, \mathrm{Cu}, \mathrm{Zn}, \mathrm{Pb}$ and $\mathrm{Co}$ were determined in the liquid sample solution using Unicom Sp. 1900 Atomic Absorption.

\section{Results and Discussion}

\section{General analysis}

The percentages of crude protein, ash, fat, fibers and nitrogen free extract of the dried material are presented in Table 1. In general, results demonstrate minor variation between leaves, stems or roots regarding to their chemical composition. However, the sampling season on which the plant materials were collected showed little variation in the chemical constituents. Crude proteins showed higher values in 
samples collected during March (spring season) or August (summer season) rather than those harvested in December (winter season). That holds true for both the studied seasons during 2014 and 2015. On the other hand, both leaves and stems exhibited slight increase in their proteins content as compared with the roots. Ash content showed maximum concentration during March. The highest ash content was detected in leaves during the two successive seasons.

TABLE 1. Chemical composition of the dried water-hyacinth plant as the level of crude protein, ash contents, crude fat, fibers and the nitrogen free extract as distributed in different parts of the plant (values are expressed as gm/100gm Dry Wt).

\begin{tabular}{|c|c|c|c|c|c|c|c|c|}
\hline \multirow{2}{*}{$\begin{array}{c}\text { Sampling } \\
\text { dates }\end{array}$} & \multicolumn{4}{|c|}{ Season, 2014} & \multicolumn{4}{|c|}{ Season, 2015} \\
\hline & March & August & December & Mean & March & August & December & Mean \\
\hline \multicolumn{9}{|l|}{$\begin{array}{l}\text { Crude } \\
\text { Protein }\end{array}$} \\
\hline Leaves & 15.86 & 16.81 & 13.86 & 15.51 & 16.81 & 17.35 & 14.85 & 16.34 \\
\hline Stems & 17.21 & 16.03 & 12.51 & 15.25 & 18.35 & 18.21 & 13.21 & 16.57 \\
\hline Roots & 16.43 & 15.21 & 12.33 & 14.66 & 17.26 & 17.22 & 12.98 & 15.82 \\
\hline Mean & 16.5 & 16.02 & 12.9 & & 17.47 & 17.59 & 13.66 & \\
\hline \multicolumn{9}{|l|}{ ASH } \\
\hline Leaves & 17.11 & 12.83 & 12.33 & 14.09 & 18.08 & 13.51 & 12.53 & 1471 \\
\hline Stems & 14.83 & 10.16 & 10.22 & 11.74 & 15.13 & 12.26 & 11.82 & 1307 \\
\hline Roots & 15.22 & 11.25 & 11.85 & 12.77 & 16.28 & 10.35 & 10.31 & 1231 \\
\hline Mean & 15.72 & 11.41 & 11.47 & & 16.49 & 12.04 & 11.55 & \\
\hline \multicolumn{9}{|l|}{ Crude Fat } \\
\hline Leaves & 2.85 & 4.36 & 5.96 & 4.36 & 3.08 & 5.11 & 5.92 & 4.70 \\
\hline Stems & 1.89 & 3.25 & 3.98 & 3.04 & 2.11 & 4.21 & 4.36 & 3.56 \\
\hline Roots & 2.08 & 3.93 & 3.11 & 3.04 & 2.43 & 3.85 & 4.08 & 3.45 \\
\hline Mean & 2.27 & 3.85 & 4.32 & & 2.54 & 4.39 & 4.79 & \\
\hline \multicolumn{9}{|l|}{ Fibers } \\
\hline Leaves & 21.15 & 18.87 & 18.35 & 19.46 & 19.11 & 17.65 & 19.16 & 18.64 \\
\hline Stems & 25.30 & 19.36 & 22.45 & 22.37 & 23.56 & 18.34 & 21.35 & 21.08 \\
\hline Roots & 24.86 & 20.21 & 23.16 & 22.74 & 25.11 & 19.85 & 22.38 & 22.45 \\
\hline Mean & 23.77 & 19.48 & 21.32 & & 22.59 & 18.61 & 20.96 & \\
\hline \multicolumn{9}{|l|}{\begin{tabular}{|l|} 
Nitrogen \\
Free Extract \\
\end{tabular}} \\
\hline Leaves & 43.03 & 47.13 & 49.60 & 46.59 & 42.92 & 46.38 & 47.54 & 45.61 \\
\hline Stems & 40.77 & 51.20 & 50.84 & 47.60 & 40.85 & 46.98 & 49.31 & 45.71 \\
\hline Roots & 41.41 & 49.40 & 49.55 & 46.79 & 38.92 & 48.73 & 50.31 & 45.99 \\
\hline Mean & 41.74 & 49.24 & 49.99 & & 40.89 & 47.36 & 49.05 & \\
\hline
\end{tabular}


Naturally, fat was found relatively within low concentration in the waterhyacinth plant organs. Samples collected during December (winter season) showed the maximum fat contents rather than those collected during March or August for both the consequent seasons namely 2014 and 2015. The leaves exhibited comparatively higher fat content than that of stems or roots.

Fiber content exhibited the following decreasing order during the two studied seasons:

March (spring season) > December (winter season) > August (summer season)

However, the plant organs exhibited the following decreasing order in terms of their fiber contents:

Roots > stems > leaves

Nitrogen free extract was the predominant fraction as compared with the other determined component in water-hyacinth. However, its fluctuation during the different sampling dates could be arranged as follows:

December (winter season) > August (summer season) $>$ March (spring season)

Thus, it could be concluded that there was negative correlation between nitrogen free extract content and both crude protein and ash content. However, no detectable variation could be found between the different plant organs in terms of their nitrogen free extract content.

Previous investigators mentioned variable values for the chemical analysis of water-hyacinth as compared with the data given here. For instance, El-Falaky et al. ${ }^{(8)}$ declared that water-hyacinth contains $10 \%$ crude protein, $11 \%$ ash and $79 \%$ organic matter. On the other hand, About-Bakr et al. ${ }^{(4)}$ reported that water-hyacinth contained $49.6 \%$ protein, $16 \%$ total lipids, $26.9 \%$ total carbohydrates, $11.7 \%$ fiber and $5.8 \%$ ash. Such variation is expected and may be attributed to the quality, biological and chemical nature of the aquatic environment from which the plants were collected.

\section{Sugars and carbohydrates content}

Leaves, stems or roots of water-hyacinth plant showed considerable variations with regard to their sugars and carbohydrates contents. In this respect, stems exerted maximum reducing sugars content. On the other side, leaves of water-hyacinth exhibited the highest values of non-reducing and total sugar contents followed by stems and roots (Table 2). 
TABLE 2. Sugars and carbohydrates content of dried water-hyacinth partitioned plant samples into leaves, stems and roots (as mg/g Dry Wt).

\begin{tabular}{|c|c|c|c|c|c|c|c|c|}
\hline \multirow{2}{*}{$\begin{array}{c}\text { Sampling } \\
\text { dates }\end{array}$} & \multicolumn{4}{|c|}{ Season, 2014} & \multicolumn{4}{|c|}{ Season, 2015} \\
\hline & March & August & December & Mean & March & August & December & Mean \\
\hline \multicolumn{9}{|l|}{$\begin{array}{l}\text { Reducing } \\
\text { sugars }\end{array}$} \\
\hline Leaves & 12.35 & 11.15 & 15.16 & 12.89 & 14.31 & 13.61 & 16.15 & 14.69 \\
\hline Stems & 22.31 & 22.35 & 13.31 & 19.32 & 20.51 & 22.08 & 14.16 & 18.92 \\
\hline Roots & 10.15 & 12.61 & 14.56 & 12.44 & 14.61 & 15.55 & 12.15 & 14.10 \\
\hline Mean & 14.94 & 15.37 & 14.34 & & 16.48 & 17.08 & 14.15 & \\
\hline \multicolumn{9}{|l|}{$\begin{array}{l}\text { Non-reducing } \\
\text { sugars }\end{array}$} \\
\hline Leaves & 38.25 & 40.15 & 32.15 & 36.85 & 40.15 & 45.61 & 38.11 & 41.29 \\
\hline Stems & 25.16 & 30.61 & 18.61 & 24.79 & 32.11 & 25.38 & 20.16 & 25.88 \\
\hline Roots & 20.33 & 18.51 & 12.11 & 16.98 & 19.85 & 21.08 & 18.11 & 19.68 \\
\hline Mean & 27.91 & 29.76 & 20.96 & & 30.70 & 30.69 & 25.46 & \\
\hline \multicolumn{9}{|l|}{ Total sugars } \\
\hline Leaves & 50.60 & 51.30 & 47.31 & 49.74 & 54.46 & 59.22 & 54.26 & 55.98 \\
\hline Stems & 47.47 & 52.96 & 31.92 & 44.12 & 52.62 & 47.46 & 34.32 & 44.80 \\
\hline Roots & 30.48 & 31.12 & 26.67 & 29.42 & 34.46 & 36.63 & 30.26 & 33.78 \\
\hline Mean & 42.85 & 45.13 & 35.30 & & 47.18 & 47.77 & 39.61 & \\
\hline \multicolumn{9}{|l|}{$\begin{array}{l}\text { Total } \\
\text { carbohydrates }\end{array}$} \\
\hline Leaves & 283.51 & 335.11 & 311.92 & 310.18 & 295.53 & 354.08 & 308.40 & 316.34 \\
\hline Stems & 298.70 & 336.81 & 275.60 & 303.70 & 308.20 & 356.15 & 297.45 & 320.60 \\
\hline Roots & 247.08 & 324.15 & 265.31 & 278.85 & 267.11 & 311.70 & 288.51 & 289.11 \\
\hline Mean & 276.43 & 332.02 & 284.28 & & 290.28 & 337.64 & 298.12 & \\
\hline
\end{tabular}

The same trend was noticed for total carbohydrate contents regarding its distribution in the different organs of water-hyacinth, (i.e. leaves $>$ stems $>$ roots). That holds true for both the successive seasons.

On the other hand, the recorded sugars and carbohydrates content showed no fixed trend alongside the different sampling seasons. In other words, some fluctuations were detected during the course of the present study. It is most likely that water-hyacinth samples harvested during the summer (in August) 
exerted maximum sugars and carbohydrates content rather than those collected in spring (March) and winter (December).

Uptake of metals by water-hyacinth

Results are given in Table 3. These results demonstrate the metals content in the dried water-hyacinth samples during different sampling seasons.

TABLE 3. Level of $\mathrm{Na}, \mathrm{K}, \mathrm{Ca}, \mathrm{Mg}$ and $\mathrm{Mn}$ in the dried water-hyacinth plant samples as partitioned into leaves, stems and roots $(\mathrm{mg} / 100 \mathrm{~g}$ as dry wt.)

\begin{tabular}{|c|c|c|c|c|c|c|c|c|}
\hline \multirow{2}{*}{$\begin{array}{c}\text { Sampling } \\
\text { dates }\end{array}$} & \multicolumn{4}{|c|}{ Season, 2014} & \multicolumn{4}{|c|}{ Season, 2015} \\
\hline & March & August & December & Mean & March & August & December & Mean \\
\hline \multicolumn{9}{|l|}{$\mathbf{N a}$} \\
\hline Leaves & 1325.2 & 1033.5 & 883.5 & 1080.7 & 1453.6 & 1225.5 & 936.8 & 1205.3 \\
\hline Stems & 1158.6 & 1105.4 & 936.7 & 1066.9 & 1533.8 & 1186.3 & 1018.5 & 1246.2 \\
\hline Roots & 1083.5 & 1125.6 & 745.5 & 984.9 & 1644.9 & 1221.5 & 1145.3 & 1337.2 \\
\hline Mean & 1189.1 & 1088.2 & 855.2 & & 1544.1 & 1211.1 & 1033.5 & \\
\hline \multicolumn{9}{|l|}{$\mathbf{K}$} \\
\hline Leaves & 1125.5 & 1221.5 & 925.5 & 1090.8 & 1325.6 & 1535.5 & 1143.0 & 1334.7 \\
\hline Stems & 1236.4 & 1155.6 & 843.4 & 1078.5 & 1435.5 & 1643.2 & 1256.5 & 1445.1 \\
\hline Roots & 1145.5 & 1030.5 & 716.5 & 964.2 & 1611.4 & 1745.9 & 1125.3 & 1494.2 \\
\hline Mean & 1135.8 & 1135.9 & 828.5 & & 1457.5 & 1641.5 & 1174.9 & \\
\hline \multicolumn{9}{|l|}{$\mathbf{C a}$} \\
\hline Leaves & 853.5 & 897.4 & 683.4 & 811.4 & 983.6 & 925.4 & 781.5 & 896.8 \\
\hline Stems & 711.8 & 808.2 & 761.5 & 760.5 & 835.4 & 731.5 & 613.4 & 726.8 \\
\hline Roots & 643.5 & 765.4 & 645.4 & 684.8 & 806.1 & 811.5 & 633.8 & 750.5 \\
\hline Mean & 736.3 & 823.7 & 696.8 & & 875.1 & 822.8 & 676.2 & \\
\hline \multicolumn{9}{|l|}{ Mg } \\
\hline Leaves & 835.5 & 783.5 & 516.5 & 711.8 & 911.5 & 815.5 & 483.5 & 736.8 \\
\hline Stems & 683.4 & 611.3 & 443.7 & 579.5 & 833.2 & 733.6 & 566.6 & 711.1 \\
\hline Roots & 715.2 & 583.4 & 411.4 & 570.0 & 954.8 & 683.5 & 453.3 & 697.2 \\
\hline Mean & 744.7 & 659.4 & 457.2 & & 899.8 & 744.2 & 501.1 & \\
\hline \multicolumn{9}{|l|}{ Mn } \\
\hline Leaves & 436.3 & 583.4 & 327.8 & 449.2 & 531.8 & 673.2 & 435.2 & $\begin{array}{l}546.7 \\
\end{array}$ \\
\hline Stems & 325.2 & 617.5 & 435.4 & 459.4 & 614.5 & 711.5 & 531.3 & 619.1 \\
\hline Roots & 411.5 & 538.1 & 311.5 & 420.4 & 533.1 & 615.4 & 387.8 & 512.1 \\
\hline Mean & 391.0 & 579.7 & 358.2 & & 559.8 & 666.7 & 451.4 & \\
\hline
\end{tabular}

Egypt. J. Chem. 59, No.2 (2016) 
TABLE 3. Cont.

\begin{tabular}{|c|c|c|c|c|c|c|c|c|}
\hline \multirow{2}{*}{$\begin{array}{l}\text { Sampling } \\
\text { dates }\end{array}$} & \multicolumn{4}{|c|}{ Season, 2014} & \multicolumn{4}{|c|}{ Season, 2015} \\
\hline & March & August & December & Mean & March & August & December & Mean \\
\hline \multicolumn{9}{|l|}{$\mathbf{Z n}$} \\
\hline Leaves & 435.6 & 511.6 & 318.7 & 421.9 & 531.7 & 598.8 & 425.5 & 518.7 \\
\hline Stems & 531.8 & 631.7 & 323.5 & 495.7 & 666.8 & 687.4 & 398.6 & 584.3 \\
\hline Roots & 518.4 & 598.4 & 411.8 & 509.5 & 618.5 & 683.1 & 325.4 & 542.3 \\
\hline Mean & 495.3 & 580.6 & 351.3 & & 605.7 & 858.4 & 383.2 & \\
\hline \multicolumn{9}{|l|}{$\mathrm{Cu}$} \\
\hline Leaves & 68.3 & 83.4 & 58.8 & 70.17 & 79.8 & 91.33 & 60.25 & 77.13 \\
\hline Stems & 54.5 & 65.1 & 48.8 & 56.14 & 66.5 & 66.8 & 63.18 & 65.49 \\
\hline Roots & 53.2 & 73.6 & 41.2 & 56.02 & 54.8 & 71.8 & 48.61 & 58.4 \\
\hline Mean & 58.7 & 74.0 & 49.6 & & 67.03 & 76.6 & 57.35 & \\
\hline \multicolumn{9}{|l|}{$\mathbf{P b}$} \\
\hline Leaves & 2.3 & 18.6 & 7.8 & 9.58 & 4.5 & 21.3 & 9.4 & 11.73 \\
\hline Stems & 4.2 & 19.2 & 5.1 & 9.51 & 5.3 & 25.6 & 7.5 & 12.80 \\
\hline Roots & 3.5 & 8.6 & 4.3 & 5.48 & 4.7 & 22.8 & 9.5 & 12.33 \\
\hline Mean & 3.3 & 15.5 & 5.7 & & 4.8 & 23.2 & 8.8 & \\
\hline \multicolumn{9}{|l|}{$\mathrm{Fe}$} \\
\hline Leaves & 416.5 & 561.3 & 337.8 & 438.5 & 533.4 & 665.5 & 216.5 & 471.8 \\
\hline Stems & 325.4 & 611.5 & 215.5 & 384.1 & 466.8 & 638.4 & 245.3 & 450.2 \\
\hline Roots & 319.5 & 525.1 & 208.6 & 351.1 & 401.0 & 559.4 & 200.6 & 387.0 \\
\hline Mean & 353.8 & 565.9 & 253.9 & & 467.1 & 621.1 & 220.8 & \\
\hline \multicolumn{9}{|l|}{ Co } \\
\hline Leaves & 30.1 & 35.8 & 37.8 & 34.57 & 25.6 & 23.4 & 25.8 & 24.9 \\
\hline Stems & 25.2 & 30.5 & 35.5 & 30.40 & 21.8 & 26.5 & 27.3 & 25.2 \\
\hline Roots & 22.7 & 28.4 & 31.8 & & 20.2 & 28.4 & 21.5 & 20.0 \\
\hline Mean & 26.0 & 31.6 & 35.0 & & 22.5 & 22.8 & 24.9 & \\
\hline
\end{tabular}

Egypt. J. Chem. 59, No. 2 (2016) 
From the results, it is obvious that sodium, potassium, magnesium and calcium are the predominant elements. Iron, Zinc and manganese occurred in relatively moderate concentrations. On the other hand, copper, lead and cobalt were within very low concentration in correlation with the above mentioned metals.

During the two studied seasons, sodium was found within high level in samples taken during March or August rather than those of December. Meanwhile, leaves of water-hyacinth showed maximum sodium content during season 2014. However, roots exerted the highest sodium level in the second season (2015).

Narrow pattern variation could be observed with regard to potassium and magnesium as they exhibited higher levels in the earlier sampling dates (March or August). However, the distribution of both potassium and magnesium in the different organs varied according to the sampling dates and the growing season. The highest potassium level was detected in plant leaves related to 2014 samples. However, the highest potassium level was shown in roots of plants collected in 2015 .

Calcium showed maximum content in August (summer) of 2014 and March (spring) 2015, respectively. Manganese, Zinc and iron exhibited another trend in response to their fluctuation in water-hyacinth tissues during the different sampling season. Samples collected in the summer (August), exhibited the maximum level for the last mentioned three elements namely, Fe, Mn and $\mathrm{Zn}$. However, comparatively very low concentration was recorded in plant samples that were collected in March or December during both the studied seasons.

Nevertheless, no regular trend could be noticed in response to the distribution of these elements in the different plant organs.

Maximum lead content was recorded in August of both the studied seasons. However, maximum cobalt content was determined in plants that were sampled during December season. El-Falaky et al. ${ }^{(8)}$ reported that the accumulation of metals by water-hyacinth depends on the initial concentration of the nutrient elements in water, the period of growth and the plant part namely, leaves stems or roots. Abdel-Shafy et al. ${ }^{(28)}$, reported that metals are accumulated mostly by plant roots followed by leaves and that metals are less accumulated by the stems. Abdel-Haleem, et al. ${ }^{(6)}$ reported that water-hyacinth plant is a good tool for water profile in monitoring the aquatic environment and it could reflect the situation of the investigated water-contamination. Meanwhile, other investigators $(2,24,28)$ stated that in the aquatic environment, accumulation of metals by plants is depending on the level of metals in the aquatic system, salinity, period of growth as well as the type of metal. 


\section{Conclusions}

The overall results reveal that water-hyacinth plant contains considerable nutrient elements. Meanwhile, the plant has the potential of accumulating certain metals from the surrounding aquatic environment. Furthermore, the plant parts namely the roots, stems and leaves has variable chemical constituents. These plant parts have also variable capacity towards accumulation of metals from the aquatic environment. It can be concluded from the above study that the water-hyacinth plants can be used as animal fodders due to their valuable nutrient contents. However, care must be taken not to collect such plant from contaminated water to avoid any accumulation of heavy metals by this aquatic plant. Therefore, heavy metal contents must be detected in the fodders before use. Moreover, water-hyacinth plant could be employed as bioindicator to the contamination of the aquatic system.

\section{References}

1. El-Kadi, O.A.T., Influence of some natural local amendments on the reclamation of sandy soils of the Tahreer province. ARE M.Sc. Thesis. Fac. of Agric., Cairo Univ (1978).

2. Fayed, S.E. and Abdel-Shafy, H.I. "Accumulation of $\mathrm{Cu}, \mathrm{Zn} \mathrm{Cd}$ and $\mathrm{Pb}$ by aquatic macrophytes. J. Environmental International, 11, 77-87 (1985).

3. Fayed, S.E. and Abdel-Shafy H.I., Accumulation of $\mathrm{Cd}, \mathrm{Cu}, \mathrm{Pb}$ and $\mathrm{Zn}$ by algae. Egyptian J. Microbiology, 21(2), 263-274 (1986).

4. Abou-Bakir, T.M., El-Shemi, N.M. and Mesallam, A.S., lsolation and chemical evaluation of protein from water hyacinth Qual plant-plant foods . Ham. Nutr. 34, 67-73 (1984).

5. Austin, J.R., Simon, S.J., Williams, L. and Beckert, W.F., New biological reference materials in vivo incorporation toxic metals in water-hyacinth tissues. ASTM Spec. Tech. Publ. 867, 305-3/6. (1985).

6. Abdel-Haleem, A.S., Abdel-Sabour, M.F. and Zaghloul, R.A., The use of water hyacinth as biological indicator of environmental contamination by heavy metals. Proc. Conf. in Environmental Contamination, CEP, consultant ltd., UK., pp. 263265. (1992).

7. Abdel-Shafy, H.I., Hegemann, W. and Teiner, A., Accumulation of metals by Vascular plants. J. Environmental Management and Health, 5(2), 21-24 (1994).

8. El-Falaky, A., Labib, T.M. and Hamed, T.H., Studies on water pollution in Hellwan industrial district, Egypt. Water Sci. 4, 65 - 69 (1988).

9. Abdel-Shafy H.I., Hindy, K.I. and Abdel-Sabour , M.F., Heavy metals in the environment of Ismailia City, Egypt. International Environmental Studies, 39, 279289 (1992).

Egypt. J. Chem. 59, No. 2 (2016) 
10. Abdel-Shafy, Hussein I., Environmental transformation of bioenergy via the anaerobic digestion "Environment Xenobiotic" M. Richardson (Ed.) Taylor \& Francis Ltd. Publisher London, pp.95-119. (1996).

11. Abdel-Shafy, Hussein I. and Abdel-Sabour, M.F. In: P. Hlavinek et al. (Ed.), Integrated Urban Water Resource s Management, Springer Publisher, Netherland, pp. 301-312. (2006) .

12. Bixio, D. and Wintgens, Th. (Ed.), Water Reuse System Management Manual.AQUARIC, Office for Official Publication of the European Commission, Luxembourg (2006).

13. Abdel-Sabour, M.F., Abdel-Shafy, H.I. and Mohamed, A.R.A.G., J. Sustainable Water Management, 1, 27-31 (2005).

14. Nasr, F.A. and Abdel-Shafy, H.I., Biodegradation of sewage sludge. Environmental Management \& Health, 3 (4), 18-25 (1992).

15. Abdel-Shafy, H. I. and Mansour, Mona S.M., Biogas production as affected by heavy metals in the anaerobic digestion of sludge. Egyptian J. Petroleum, Jan. (2015) 23(4), 409-417, (2014).

16. Abdel-Shafy, H. I., and Al-Sulaiman, A. M., Efficiency of degreasing / settling tank followed by constructed wetland for greywater treatment. Egyptian J. Chemistry, 57(5, 6), 435-446 (2014).

17. Ahmed, S.A., Ito, M. and Ueki, K., phyto-toxic effect of water-hyacinth extract and decayed residue. Weed Research Japan. 27, 177-183 (1982).

18. Gamal-El-Din. H. and Badr-El-Din, S.M., Antimicrobial and phyto-toxic effect of a substance isolated from water-hyacinth. Forum Staedte-Hyg., 37, 23 - 26 (1986).

19. Abdel-Shafy, H. I., Martin Regelsberger, Fabio Masi, Christian Platzer and Mohamed A. El-Khateeb, Constructed wetland in Egypt Sustainable water management. Journal of the EU project "Sustainable Concepts towards a Zero Outflow Municipality" (Zer0-M), n 3/2008, 3, 10-14 (2008).

20. Abdel-Shafy, H. I., El-Khateeb, M.A., Regelsberger, M., El-Sheikh R. and Shehata, M., Integrated system for the treatment of blackwater and greywater via UASB and constructed wetland in Egypt. Desalination and Water Treatment, 8, 1-7 (2009).

21. Masi, F., El Hamouri, B., Abdel Shafy, H., Baban, A., Ghrabi, A. and Regelsberger, M., "Treatment of segregated black/grey domestic wastewater using constructed wetlands in the mediterranean basin: the Zero-m Experience" Water Science and Technology, 61(1), 97-105, 2010. doi:10.2166/wst.2010.780 (2010).

22. Abdel-Shafy, H. I. and Ahmed Dewedar, Constructed wetlands for urban wastewater treatment in Egypt. J. Sustainable Sanitation Practice, 12, pp. 27-32 (2012). 
23. Abdel-Shafy, H. I., Al-Sulaiman, A. M., Galal-El-Deen, Mona M. and AbdelHameed, H. S., Greywater treatment via integration effective miro-organisms and constructed wetlands. J. Engineering \& Applied Science, 60(5), Oct., (2013).

24. Abdel-Sabour, M.F., Abdel-Shafy, H.I. and Mosalem T.M., Heavy metals and plant growth yield as effected by sewage sludge and water hyacinth compost applied to sandy soil. J. Environmental Protection Engineering, 27(2), 43-53 (2001)

25. Abdel-Shafy, H. I. and El-Khateeb, M. A., Integration of septic tank and constructed wetland for the treatment of wastewater in Egypt. J. Desalination and Water Treatment, Taylor \& Francis Publisher, 51, 3539-3546 April, (2013).

26. A.O.A.C. Official Methods of Analysis of the Association of Official Analytical Chemists, $12^{\text {th }}$ ed., Washington. D. C. 20044. (1985).

27. Dubois, M., Gilles, K.A., Hamiltion, J.K., Rebers, P.A. and Smith, F., Colorimetric method for determination of sugars and relatedted substances. Anal. Chem. 28, 350-356 (1956).

28. Abdel-Shafy, H.I., Cooper, W. J., Handley-Raven, L.L. and Casey, L.S., Shortterm fate of heavy metals in the gravel bed hydroponics wastewater treatment system. J. Environmental Protection Engineering, 12(1), 61-80 (1986).

(Received 14/12/2015; accepted 31/12/2015) 


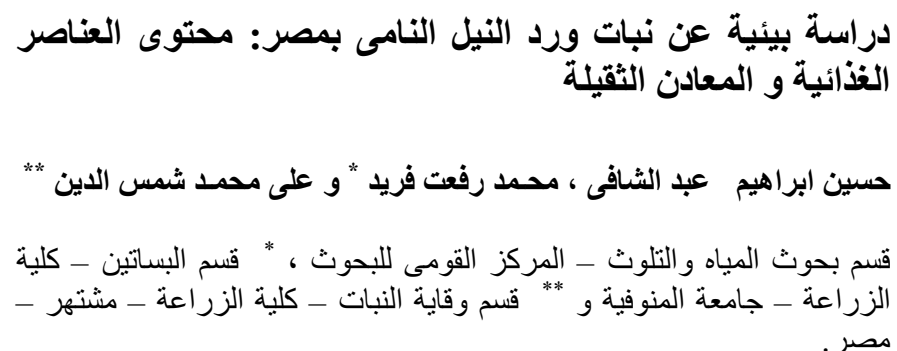

يهدف هذا العمل الى دراسة نبات ورد النيل الذى ينمو فى مجرى نهر النه النيل

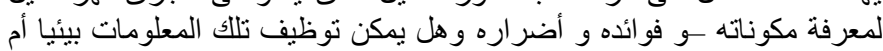

لذلك تم أخذ عينات نبات ورد النيل من المجرى الرئيسى لنهر النيل فى منطقة النيّة

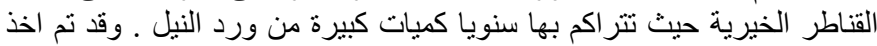

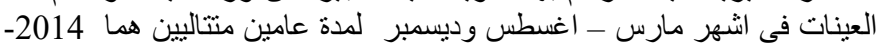

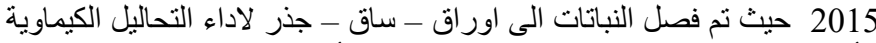

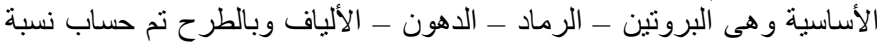

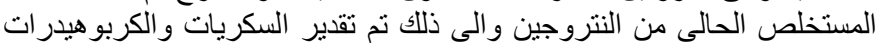

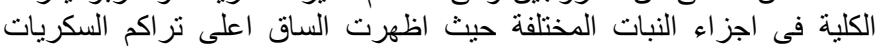

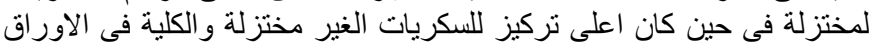
وذللك خلال موسمى الدر ساسة.

ولقد اظهر تحليل العناصر وجود كل من الصوديوم - البوناسيوم -

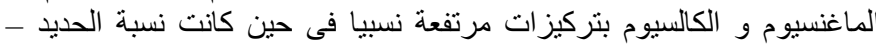

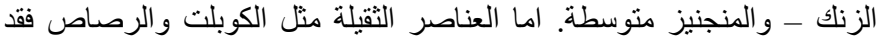

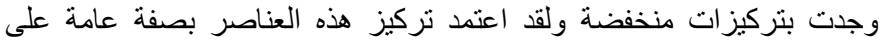

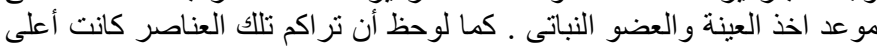

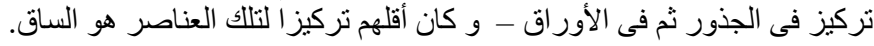

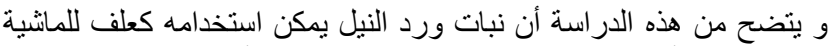

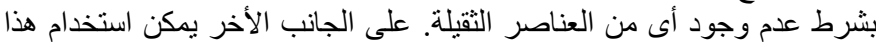

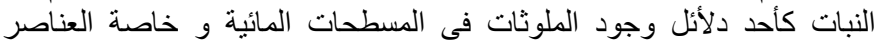


Table (3) Level of $\mathrm{Zn}, \mathrm{Cu}, \mathrm{Pb}, \mathrm{Fe}$ and $\mathrm{Co}$ in the dried water-hyacinth plant samples as partitioned into leaves, stems and roots (mg/100g as dry wt.) 
H. I. Abdel Shafy et al.

Egypt. J. Chem. 59, No. 2 (2016) 